\title{
Culture of SARS-CoV-2 in a panel of laboratory cell lines, permissivity, and differences in growth profile
}

\author{
Nathalie Wurtz ${ }^{1,2} \cdot$ Gwilherm Penant $^{1} \cdot$ Priscilla Jardot $^{1} \cdot$ Nathalie Duclos $^{1} \cdot$ Bernard La Scola $^{1,2}$ (E)
}

Received: 2 June 2020 / Accepted: 20 November 2020 / Published online: 2 January 2021

(C) Springer-Verlag GmbH Germany, part of Springer Nature 2021

\begin{abstract}
The emergence of COVID-19 disease due to SARS-CoV-2 at the end of 2019 was rapidly associated with the isolation of the strain from co-culture onto VERO cells. These isolations quickly made it possible to carry out the first tests for antiviral agents' susceptibility and drug repurposing. However, it seems important to make an inventory of all the cells that can support the growth of this virus and evaluate possible differences between isolates. In the present work, we tested 4 strains of SARS-CoV-2 locally isolated on a panel of 34 cell lines present in our laboratory and commonly used for the isolation of human pathogenic microorganism. After inoculation, cells were observed for cytopathic effects and quantitative real-time polymerase reaction was used to measure the virus replication on the cells. We were able to obtain growth on 7 cell lines, 6 simian, and the human Caco-2. The cytopathogenic effects are variable, ranging from lysis of the cell monolayer in 48-72 h to no cytopathic effect in spite of intense multiplication, as in Caco-2 cells. Interestingly, effect and multiplication varied widely according to the strain tested. In this paper, we explored the species specificity and tissue tropism of SARS-CoV-2 in vitro on a panel of cells available in our laboratory and identified human and animal cell lines susceptible to support SARS-CoV-2 replication. Our work highlights the importance of testing multiple strains when testing antiviral molecules and performing patho-physiological analyzes.
\end{abstract}

Keywords SARS-Cov $2 \cdot$ Covid- $19 \cdot$ Coronavirus $\cdot$ Culture $\cdot$ Cell lines

\section{Introduction}

The current outbreak of the novel severe acute respiratory syndrome (2019-nCov then Covid-19) due to severe acute respiratory syndrome coronavirus 2 (SARS-Cov-2) started in Wuhan, China, in late December 2019 and has spread to many other countries [1-4]. To date, more than 84,000 cases and more than 4600 deaths have been reported across China due to SARS-Cov2, mostly in the region of Hubei (WHO, [5]). SARS-Cov-2 has disseminated in 188 countries, with currently more than 52 million confirmed cases and 1 million deaths around the world.

Coronaviruses are enveloped, positive single-stranded large RNA viruses that infect also a wide range of animals.

Nathalie Wurtz and Gwilherm Penant contributed equally to this work.

Bernard La Scola

bernard.la-scola@univ-amu.fr

1 Aix Marseille University, IRD, AP-HM, MEPHI, Marseille, France

2 Institut Hospitalo-Universitaire Méditerranée-Infection, Marseille, France
The first description of coronavirus was made in 1966 by Tirell and Bynoe, who cultivated the viruses from patients with colds [6]. They were named coronavirus because of their morphology, spherical virions with a core shell and surface resembling to a solar crown, in Latin corona. Coronaviruses are divided into 4 subfamilies alpha, beta, delta and gammacoronaviruses. The first two originate from mammals, in particular bats, while the other two come from pigs and birds. The genome size of coronaviruses ranges from approximately 27 to 34 kilobases. Severe disease and fatalities are caused essentially by beta-coronaviruses, whereas alpha-coronaviruses cause asymptomatic or mildly symptomatic infections. SARS-CoV and Middle East Respiratory Syndrome coronavirus (MERS-CoV) belong to the beta-coronavirus cluster [7], as well as the SARS-CoV-2 [8].

In this crisis situation, isolation of causative virus is indispensable for developing and evaluating diagnostic tools and therapeutics assays. The first isolation of SARS-CoV-2 was performed on human airway epithelial cells in China [8]. Subsequently, like SARS-CoV and MERS-CoV [9, 10], SARS-CoV-2 was isolated on VERO cells, which are kidney epithelial cells extracted from African green monkey [11-13]. 
In this paper, we investigated the susceptibility of a number of cells lines available in our laboratory collection to SARS$\mathrm{CoV}-2$. These cells were derived from a variety of species and tissues routinely used for the culture of micro-organisms. After inoculation with SARS-CoV-2, cells were observed for cytopathic effects and quantitative real-time polymerase reaction was used to measure ongoing replication on the cells growing the virus.

\section{Materials and methods}

\section{Virus routine propagation}

SARS-CoV-2-IHUMI2, IHUMI3, IHUMI669, and IHUMI2123 strains were isolated from human nasopharyngeal swab as previously described [14] and used for all tests. The 4passage strains were grown in VERO E6 (ATCC@ CRL$1586^{\mathrm{TM}}$ ) before subculture in different cell lines in Minimum Essential Medium culture medium (Ref. 21090022, Thermo Fisher Scientific) with $4 \%$ fetal calf serum (Ref. 10270106, Thermo Fisher Scientific) and 1\% L-glutamine (Ref. 25030024, Thermo Fisher Scientific), without antibiotics at $37^{\circ} \mathrm{C}$ under $5 \% \mathrm{CO}_{2}$.

\section{Multiple cell line assays}

The cell lines tested are listed in Table 1 . These cells are either routinely or occasionally used for microorganism isolation or for various diverse research projects in our laboratory. Cell lines to be tested were inoculated in 96-well flat bottom microplates (Ref. 020035 , Dutscher) at $2 * 10^{5}$ cells $/ \mathrm{ml}$ into their specific growth medium (Table 1), without antibiotics and incubated to reach sub-confluence. At this stage, cells were infected with SARS-CoV-2 strains at $10^{-1}$ and $10^{-4}$ dilutions of VERO E6 supernatant, after filtration of $0.2 \mu$. Each day, cells were observed for SARS-CoV-2 specific cytopathic effects (CPE) for 7 days using EVOS ${ }^{\text {TM }}$ FL Digital Inverted Fluorescence Microscope (Invitrogen ${ }^{\mathrm{TM}}$ ) with $\times 10$ objective. On day 0 and day 7 after infection, supernatants were collected for subsequent quantification using reverse transcriptionpolymerase chain reaction (RT-PCR) targeting E-gene as previously described [16]. The difference of $\mathrm{Ct}$ between day 0 and Day 7 correspond to the Delta $\mathrm{Ct}(\Delta \mathrm{Ct})$. Each condition was performed in triplicate. For cells for which a CPE effect was observed, cells were incubated with 10-fold dilutions of different viruses and incubated for 7 days at $37{ }^{\circ} \mathrm{C}$. Each condition was performed in quadruplicate. Median tissue culture infectious dose $\left(\mathrm{TCID}_{50}\right)$ was determined by the Reed and Muench method [17]. All experiments involving SARS-CoV2 cultures were carried out in a Biosafety level 3 laboratory and conducted under appropriate conditions.

\section{Results}

Table 1 presents the panel of 34 cell lines present in the laboratory and tested for their susceptibility to the SARS-Cov-2 virus. Among these cell lines, 7 are able to support SARSCoV-2 multiplication and are presented in Table 2. For these seven cell lines that supported growth of the virus, the $\Delta \mathrm{Ct}$ between day 0 and day 7 at dilution $10^{-1}$ varied between 3.85 and 9.76, as shown in Table 2. Besides VERO E6 in which the virus was isolated and propagated, 4 African green monkey kidney cell lines supported replication of SARS-CoV-2 (VERO 81, VERO SLAM, MA104, and BGM cells) and produced CPE $48 \mathrm{~h}$ after SARS-CoV-2 infection. All produced evident CPEs. One human cell line supported virus replication, an epithelial cell line from colorectal adenocarcinoma (Caco-2). Caco-2 showed only discrete modification as compared to control but no real CPE.

The morphological changes observed in the different cell lines are shown in Fig. 1.

LLC-MK2, a rhesus macaque epithelial kidney cell line, did not produce evident CPE.

For these seven cell lines that supported growth of the virus, the $\Delta \mathrm{Ct}$ between day 0 and day 7 at dilution $10^{-4}$ varied between 9.37 and 17.32 as shown in Table 2. Viral multiplication was not associated with the intensity of CPE. Interestingly, according to the strain tested, major differences could be observed between permissivity, level of multiplication, and TCID50. In example, strain IHUMI2 as nearly always the highest TCID50 in spite its level of multiplication tested by RT-PCR can be lower. Twenty-seven other cell lines, derived from various species like insect, human, rodent, bovine, dog, sheep and bat cell lines, did not present any morphological changes or $\mathrm{CPE}$ and no difference of $\Delta \mathrm{Ct}$ was observed.

\section{Discussion}

In the context of the SARS-CoV-2 epidemic, it was first important to develop rapid methods to isolate the virus. This was done easily using the common VERO E6 cell line, a highly virus permissive interferon deficient cell line [18]. In order to produce the virus in large quantities for vaccine research, to identify potential antiviral compounds, to understand intracellular trafficking and to develop innovative therapeutic approach, it is important to have other cell line, especially from human origin. In this paper, we explored the species specificity and tissue tropism of SARS-CoV-2 in vitro on a panel of cells available in our microbiology laboratory and identified human and animal cell lines susceptible to support SARSCoV-2 multiplication.

Previous published reports showed that several monkey kidney cell lines are susceptible to SARS-CoV-2, specifically 


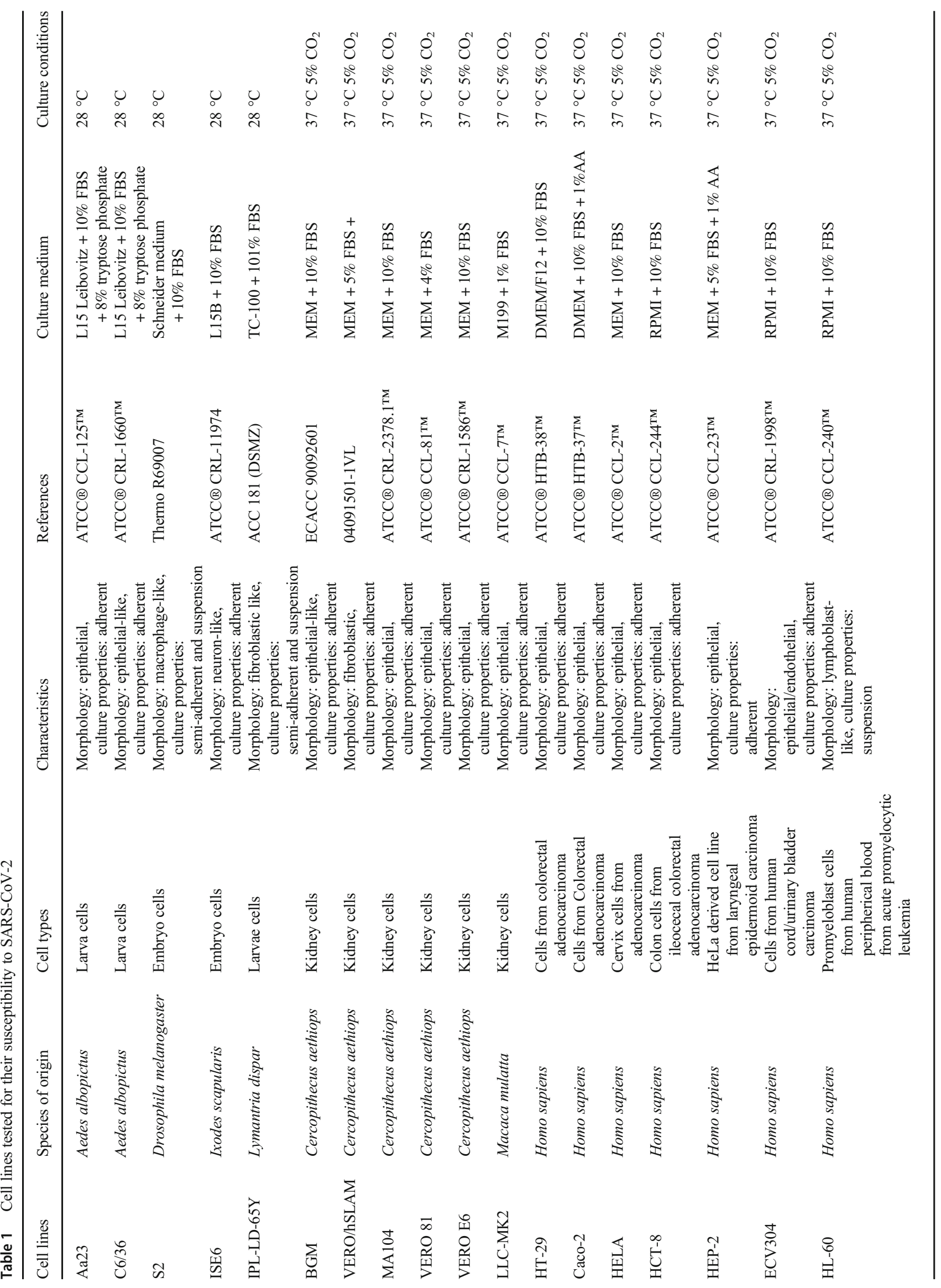




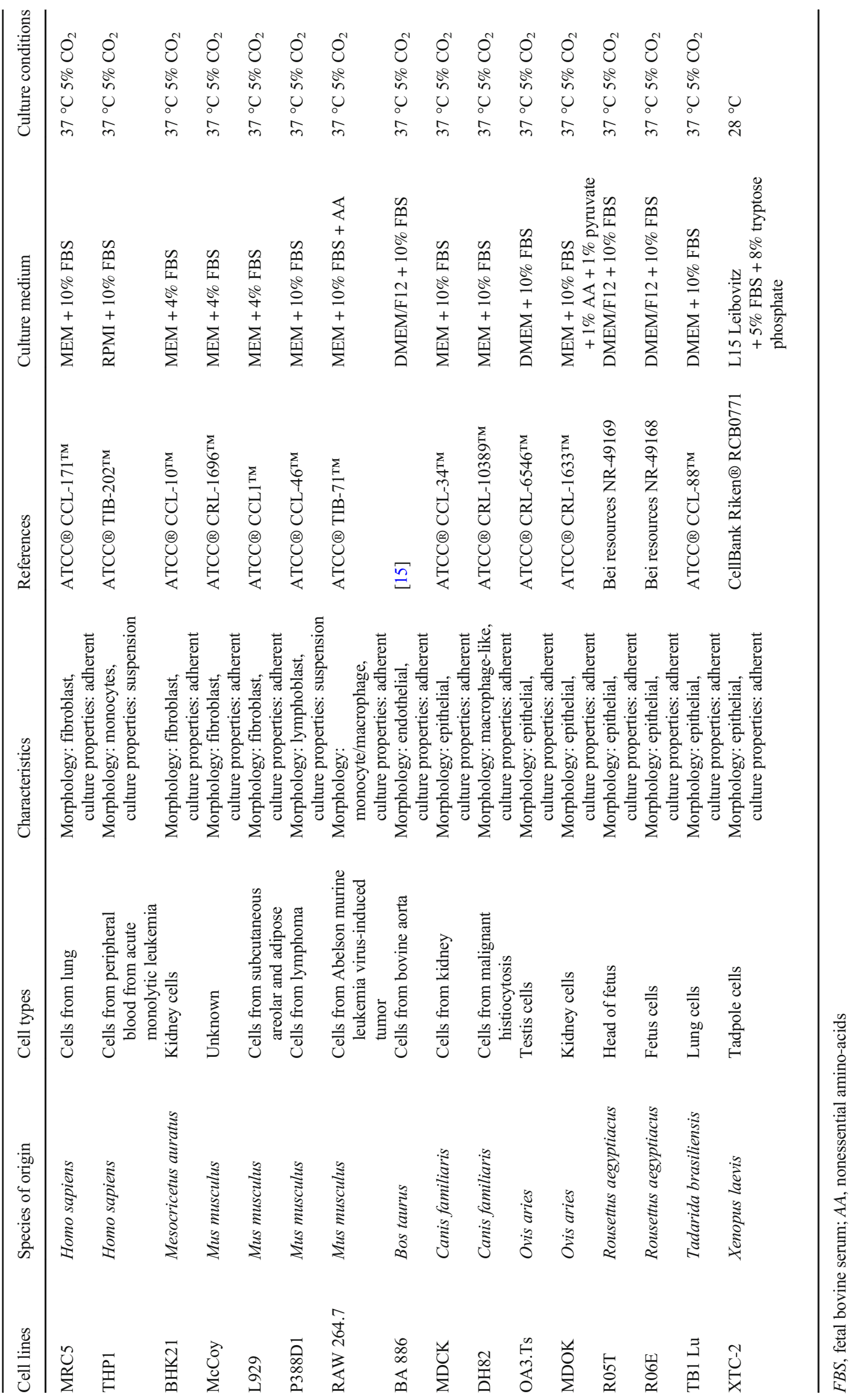




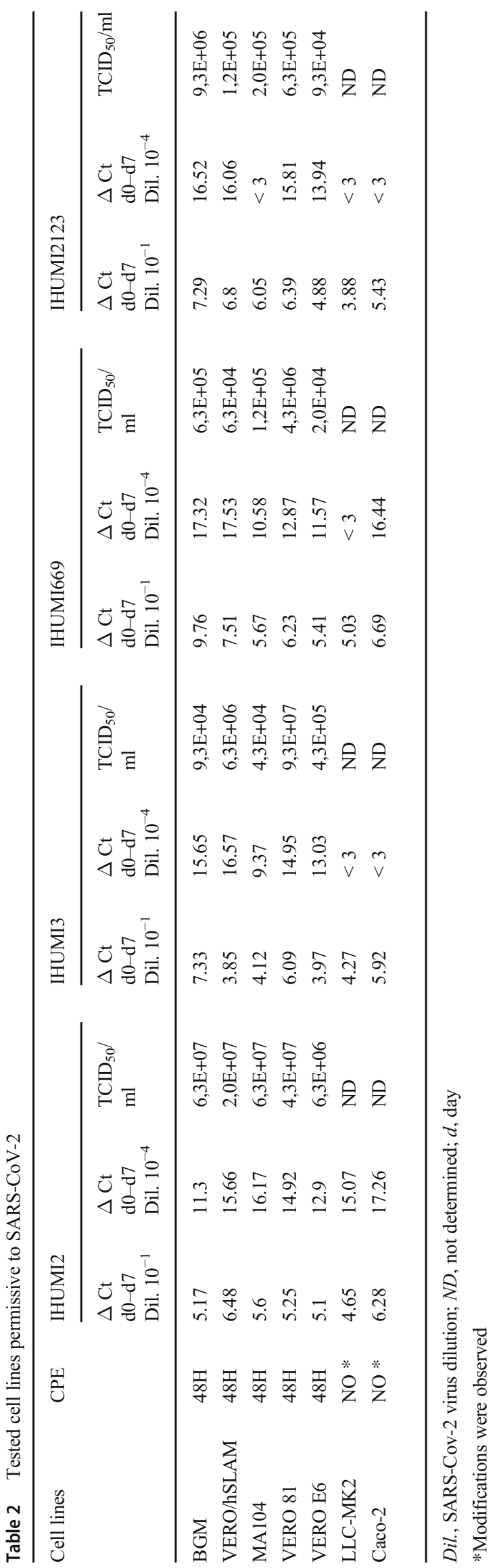

classical VERO cells, VERO E6 cells, VERO h/SLAM cells $[8,11-13,19-22]$. In this paper, we showed that all kidney cells derived from two species of monkey (African green monkey and rhesus macaque) support the growth of SARSCoV-2, and all these cells, except for LLC-MK2 cell lines, presented CPE at $48 \mathrm{~h}$ post-infection. Unsurprisingly, MA104, BGM and LLC-MK2 already tested for SARSCoV with very early CPE [23] and not previously tested with SARS-CoV-2, supported its growth.

In our first tests, HEP-2, an endothelial cell line suspected to be derived from laryngeal epidermoid carcinoma but in fact a clone derived from HELA cells [24], was first identified as susceptible to SARS-CoV-2 infection. SARS-CoV2 infection on our HEP-2 cells induced CPE after $120 \mathrm{~h}$ of infection with high virus multiplication. This result was unexpected, as previous studies on SARS-CoV showed that this virus did not infect HEP-2 cell lines, with no observable CPE or virus multiplication [23]. Based on PCR amplification of HPV18, a virus that chronically infects HEP-2 and HELA cells, we could detect that our HEP-2 cell line was misidentified. A new batch of cells ordered to the ATCC allowed to confirm that HEP-2 cells do not support growth of SARS-CoV-2.

A unique human cell line, Caco-2, epithelial cells from colorectal adenocarcinoma, was susceptible to SARS-CoV-2 with medium virus multiplication, but no specific CPE. Instead of CPE, we observed that the cell layer appears to be mottled more rapidly than in the control. This effect is rather seen in aging uninfected Caco-2. Previous studies showed that SARS-CoV and SARS-CoV-2 can infect Caco-2 cell lines $[25,26]$. For SARS-CoV infections, CPE appeared on Caco2 cell line $48 \mathrm{~h}$ post-infection [26], whereas, as observed, no obvious cell damage was found for SARS-CoV-2 infections [25]. This capability of SARS-CoV-2 to infect Caco-2 cells, could explain why patients infected with the virus present commonly gastrointestinal symptoms [27]. Moreover, SARS-CoV-2 RNA was detected in stools of patients infected with the virus, raising the question of viral gastrointestinal infection and fecal-oral transmission routes [28, 29]. However, to our knowledge, the virus could not be isolated from stools of infected patients.

We showed that 8 other human cells lines were not susceptible to SARS-CoV-2 (HEP-2, HT-29, HELA, HCT-8, ECV304, HL-60, MRC5, and THP1 cell lines). In a recent paper of Chu et al. [25], SARS-CoV-2 was inoculated on 9 human cell lines. They showed that SARS-CoV-2 replicates also on Calu3 (lung adenocarcinoma), Huh7 (hepatocellular carcinoma), U251 (glioblastoma), and 293T (embryonic kidney) cell lines, whereas no growth was observed on A549 (lung adenocarcinoma), HFL (embryonic lung fibroblasts), and RD (rhabdomyosarcoma) cell lines. These data are consistent with the results observed in our study.

In this latter study, they evaluated the cell tropism profile of SARS-CoV-2 in non-human and non-primate cells 

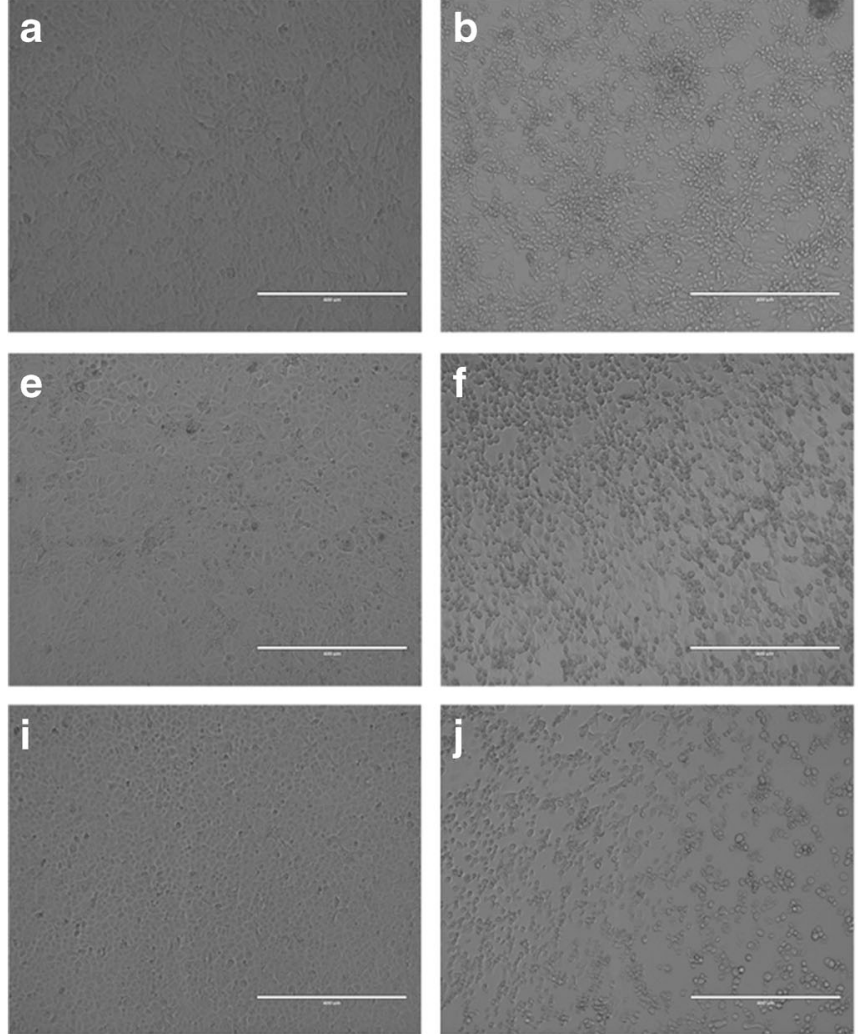

Fig. 1 Morphological changes observed in the different cell lines. a Noninfected VERO cells $(\times 10)$. b SARS-Cov- 2 infected VERO cells at $48 \mathrm{~h}$ post-infection $(\times 10)$. $\mathrm{c}$ Non infected E6 VERO cells $(\times 10)$ d SARSCov-2 infected E6 VERO cells at $48 \mathrm{~h}$ post-infection $(\times 10)$. e Noninfected VERO/hSLAM cells $(\times 10)$. f SARS-Cov-2 infected

originating from different animal species and showed that SARS-CoV-2 replicate in cat (feline kidney CRFK cells), rabbit (RK-13 rabbit kidney cells), and pig cells (PK-15 porcine kidney cells). In our study, we evaluated the susceptibility of SARS-CoV-2 in 19 animal cell lines. SARS-CoV-2 did not infect insect cells (Aa23, C6/36, S2, ISE6, and IPL-LD-65Y cells), rodent cells (BHK-21, McCoy, L929, P388 D1, and RAW 264.7 cells), bovine cells (BA886), bat cells (R05T, R06E, TB1 Lu cells), frog cells (XTC-2), dog cells (DH-2, MDCK cells), and sheep cells (OA3.Ts, MDOK cells).

Cellular entry of coronaviruses depends on the binding of the spike (S) protein to a specific cellular receptor and subsequent $\mathrm{S}$ protein priming by cellular proteases. Similarly to SARS-CoV [30, 31], SARS-CoV-2 seems to employ angiotensin-converting enzyme 2 (ACE2) as a receptor for cellular entry, and priming to be performed by the Transmembrane Serine Protease 2(TMPRSS2) [20, 32, 33]. This likely explains the specific permissivity of animal and kidney cell lines to the virus. ACE2 is expressed in various human tissues, such as heart, kidney, and testes, in addition to the lungs [34], indicating that SARS-CoV-2 may infect other tissues aside from the lungs. Moreover, Zhou et al. demonstrated that overexpressing ACE2 from different species in HeLa
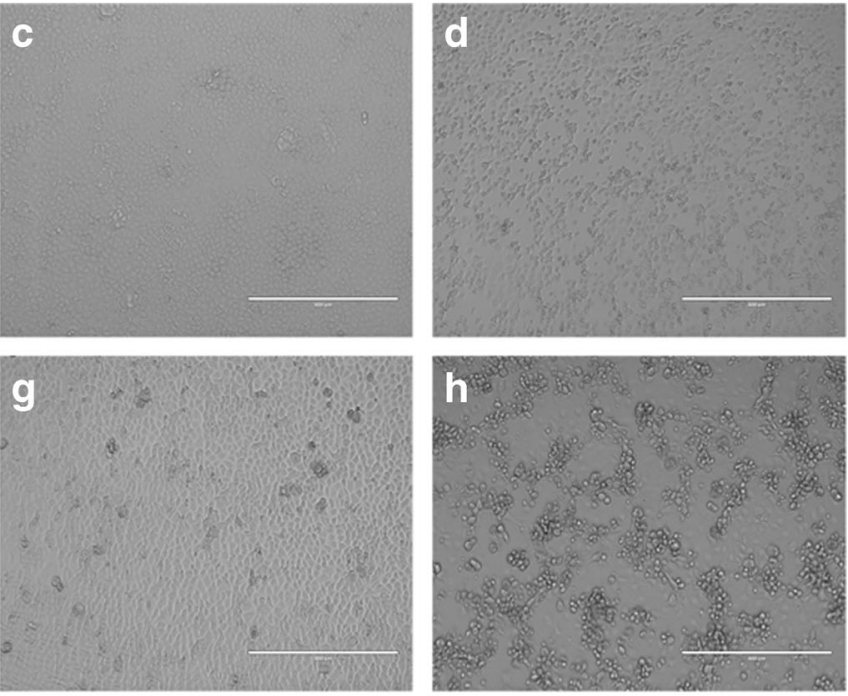

VERO/hSLAM cells at $48 \mathrm{~h}$ post-infection $(\times 10)$. g Noninfected MA104 cells $(\times 10)$. h SARS-Cov- 2 infected MA104 cells at $48 \mathrm{~h}$ postinfection $(\times 10)$. i Noninfected BGM cells $(\times 10)$. j SARS-Cov-2 infected BGM cells at $48 \mathrm{~h}$ post-infection $(\times 10)$

cells with human ACE2, pig ACE2, civet ACE2 (but not mouse ACE2) allowed SARS-CoV-2 infection and replication [20]. Hoffmann et al. reported similar findings for human and bat ACE-2 [35]. Additionally, Hoffmann et al. showed that treating VERO E6 cells, a monkey kidney cell line known to permit SARS-CoV replication, with an Anti-ACE-2 Antibody blocked the entry of vesicular stomatitis virus pseudotypes expressing the SARS-CoV-2 S protein [35]. A recent study conducted by Wang et al. reported that the existence of the novel SARS-CoV-2 (CD147-SP) route in host cells [36]. All these data suggest that SARS-CoV-2 is able to infect different tissues in human, but is also able to infect animals, and these information are concomitant with the variety of cell line that SARSCoV-2 is able to infect. Finally, using 4 different isolates sampled at different time during the epidemic, we can observe that result of growth measured by RT-PCR and TCID50 can vary greatly and independently. This is of paramount importance because most studies testing drugs, survival on surfaces and efficiency of disinfectants are usually based on test performed on a unique strain. Our work could be an explanation of some discrepant results obtained i.e. about survival of SARS-CoV-2 on different supports [37-39]. Our results suggest all phenotypic tests should rather include a panel of strains. 
Authors' contributions Wurtz Nathalie: writing-original draft preparation, analysis of results

Penant Gwilherm: methodology, investigation, writing-original draft preparation

Duclos Nathalie and Priscilla Jardot: methodology, investigation

Bernard La Scola: conceptualization, supervision, writing

Funding This work has benefited from French state support, managed by the Agence Nationale de la Recherche (ANR), including the 'Programme d'investissement d'avenir' under the reference Méditerranée Infection 101AHU-03 and Région Provence-Alpes-Côte d'Azur and European funding FEDER PRIMI.

Data availability The datasets used and/or analyzed during the current study are available from the corresponding author on reasonable request.

\section{Compliance with ethical standards}

Conflict of interest The authors declare that they no conflict of interest.

Ethics approval Not applicable

Consent to participate Not applicable

Code availability Not applicable

\section{References}

1. Al-Tawfiq JA (2020) Asymptomatic coronavirus infection: MERSCoV and SARS-CoV-2 (COVID-19). Travel Med Infect Dis. https://doi.org/10.1016/j.tmaid.2020

2. Huang Y, Tu M, Wang S, Chen S, Zhou W, Chen D et al (2020) Clinical characteristics of laboratory confirmed positive cases of SARS-CoV-2 infection in Wuhan, China: a retrospective single center analysis. Travel Med Infect Dis 2020:101606. https://doi. org/10.1016/j.tmaid.2020.101606

3. Rothan HA, Byrareddy SN (2020) The epidemiology and pathogenesis of coronavirus disease (COVID-19) outbreak. J Autoimmun 109:102433. https://doi.org/10.1016/j.jaut.2020. 102433

4. Toit AD (2020) Outbreak of a novel coronavirus. Nat Rev Microbiol 18:123. https://doi.org/10.1038/s41579-020-0332-0

5. WHO (2020) WHO Coronavirus Disease (COVID-19) Dashboard. https://covid19.who.int/. Accessed 27 May 2020

6. Tyrrell DAJ, Bynoe ML (1966) Cultivation of viruses from a high proportion of patients with colds. Lancet 287:76-77. https://doi. org/10.1016/s0140-6736(66)92364-6

7. Chen Y, Liu Q, Guo D (2020) Emerging coronaviruses: genome structure, replication, and pathogenesis. J Med Virol 92:418-423. https://doi.org/10.1002/jmv.25681

8. Zhu N, Zhang D, Wang W, Li X, Yang B, Song J et al (2020) A novel coronavirus from patients with pneumonia in China, 2019. New Engl J Med 382:727-733. https://doi.org/10.1056/ nejmoa2001017

9. Ksiazek TG, Erdman D, Goldsmith CS, Zaki SR, Peret T, Emery S et al (2003) A novel coronavirus associated with severe acute respiratory syndrome. New Engl J Med 348:1953-1966. https://doi. org/10.1056/nejmoa030781

10. Park WB, Kwon N-J, Choe PG, Choi S-J, Oh HS, Lee SM et al (2016) Isolation of Middle East respiratory syndrome coronavirus from a patient of the 2015 Korean outbreak. J Korean Med Sci 31: 315-320. https://doi.org/10.3346/jkms.2016.31.2.315

11. Matsuyama S, Nao N, Shirato K, Kawase M, Saito S, Takayama I et al (2020) Enhanced isolation of SARS-CoV-2 by TMPRSS2expressing cells. Proc Nat Acad Sci 117:7001-7003. https://doi. org/10.1073/pnas.2002589117

12. Harcourt J, Tamin A, Lu X, Kamili S, Sakthivel SK, Murray J et al (2020) Isolation and characterization of SARS-CoV-2 from the first US COVID-19 patient. Biorxiv. https://doi.org/10.1101/2020.03. 02.972935

13. Park WB, Kwon N-J, Choi S-J, Kang CK, Choe PG, Kim JY et al (2020) Virus isolation from the first patient with SARS-CoV-2 in Korea. J Korean Med Sci 35:e84. https://doi.org/10.3346/jkms. 2020.35.e84

14. La Scola B, Le Bideau M, Andreani J, Hoang VT, Grimaldier C, Colson P, et al (2020) Viral RNA load as determined by cell culture as a management tool for discharge of SARS-CoV-2 patients from infectious disease wards. Eur J Clin Microbiol Infect Dis 1-3. doi: https://doi.org/10.1007/s10096-020-03913-9

15. Yunker C, Bryom B, Semu S (1988) Cultivation of Cowdria ruminantium in bovine vascular endothelial cells. Kenya Vet 12: $12-16$

16. Amrane S, Tissot-Dupont H, Doudier B, Eldin C, Hocquart M, Mailhe M, et al (2020) Rapid viral diagnosis and ambulatory management of suspected COVID-19 cases presenting at the infectious diseases referral hospital in Marseille, France, - January 31st to March 1st, 2020: a respiratory virus snapshot. Travel Med Infect Di 101632. doi: https://doi.org/10.1016/j.tmaid.2020.101632

17. Reed LJ, Muench H (1938) A simple method of estimating fifty per cent endpoints. Am J Hyg 27:493-497. https://doi.org/10.1093/ oxfordjournals.aje.a118408

18. Desmyter J, Melnick JL, Rawls WE (1968) Defectiveness of interferon production and of rubella virus interference in a line of African green monkey kidney cells (Vero). J Virol 2:955-961

19. Kujawski SA, Wong KK, Collins JP, Epstein L, Killerby ME, Midgley CM, et al (2020) Clinical and virologic characteristics of the first 12 patients with coronavirus disease 2019 (COVID-19) in the United States. Nat Med 1-8. doi: https://doi.org/10.1038/ s41591-020-0877-5

20. Zhou P, Yang X-L, Wang X-G, Hu B, Zhang L, Zhang W et al (2020) A pneumonia outbreak associated with a new coronavirus of probable bat origin. Nature 579:270-273. https://doi.org/10.1038/ s41586-020-2012-7

21. Caly L, Druce J, Roberts J, Bond K, Tran T, Kostecki R et al (2020) Isolation and rapid sharing of the 2019 novel coronavirus (SARCoV-2) from the first patient diagnosed with COVID-19 in Australia. Med J Australia. https://doi.org/10.5694/mja2.50569

22. Kim J-M, Chung Y-S, Jo HJ, Lee N-J, Kim MS, Woo SH et al (2020) Identification of coronavirus isolated from a patient in Korea with COVID-19. Osong Public Heal Res Perspect 11:3-7. https:// doi.org/10.24171/j.phrp.2020.11.1.02

23. Kaye M, Druce J, Tran T, Kostecki R, Chibo D, Morris J et al (2006) SARS-associated coronavirus replication in cell lines. Emerg Infect Dis 12:128-133. https://doi.org/10.3201/eid1201. 050496

24. Gorphe P (2019) A comprehensive review of Hep-2 cell line in translational research for laryngeal cancer. Am J Cancer Res 9: 644-649

25. Chu H, Chan JF-W, Yuen TT-T, Shuai H, Yuan S, Wang Y et al (2020) Comparative tropism, replication kinetics, and cell damage profiling of SARS-CoV-2 and SARS-CoV with implications for clinical manifestations, transmissibility, and laboratory studies of COVID-19: an observational study. Lancet Microbe 1:e14-e23. https://doi.org/10.1016/s2666-5247(20)30004-5

26. Cinatl J, Hoever G, Morgenstern B, Preiser W, Vogel J-U, Hofmann W-K et al (2004) Infection of cultured intestinal epithelial 
cells with severe acute respiratory syndrome coronavirus. Cell Mol Life Sci Cmls 61:2100-2112. https://doi.org/10.1007/s00018-0044222-9

27. Tian Y, Rong L, Nian W, He Y (2020) Review article: gastrointestinal features in COVID-19 and the possibility of faecal transmission. Aliment Pharm Ther 51:843-851. https://doi.org/10.1111/apt. 15731

28. Xiao F, Tang M, Zheng X, Liu Y, Li X, Shan H (2020) Evidence for gastrointestinal infection of SARS-CoV-2. Gastroenterology 158:1831-1833.e3. https://doi.org/10.1053/j.gastro.2020.02.055

29. Holshue ML, DeBolt C, Lindquist S, Lofy KH, Wiesman J, Bruce $\mathrm{H}$ et al (2020) First case of 2019 novel coronavirus in the United States. New Engl J Med 382:929-936. https://doi.org/10.1056/ nejmoa2001191

30. Li W, Moore MJ, Vasilieva N, Sui J, Wong SK, Berne MA et al (2003) Angiotensin-converting enzyme 2 is a functional receptor for the SARS coronavirus. Nature 426:450-454. https://doi.org/10. 1038/nature02145

31. Matsuyama S, Nagata N, Shirato K, Kawase M, Takeda M, Taguchi F (2010) Efficient activation of the severe acute respiratory syndrome coronavirus spike protein by the transmembrane protease TMPRSS2. J Virol 84:12658-12664. https://doi.org/10.1128/jvi. 01542-10

32. Xu H, Zhong L, Deng J, Peng J, Dan H, Zeng X et al (2020) High expression of ACE2 receptor of 2019-nCoV on the epithelial cells of oral mucosa. Int J Oral Sci 12:8. https://doi.org/10.1038/s41368020-0074-X

33. Lu R, Zhao X, Li J, Niu P, Yang B, Wu H et al (2020) Genomic characterisation and epidemiology of 2019 novel coronavirus: implications for virus origins and receptor binding. Lancet 395:565574. https://doi.org/10.1016/s0140-6736(20)30251-8
34. Tipnis SR, Hooper NM, Hyde R, Karran E, Christie G, Turner AJ (2000) A human homolog of angiotensin-converting enzyme: cloning and functional expression as a captopril-insensitive carboxypeptidase. J Biol Chem 275:33238-33243. https://doi.org/10.1074/jbc. m002615200

35. Hoffmann M, Kleine-Weber H, Schroeder S, Krüger N, Herrler T, Erichsen $\mathrm{S}$ et al (2020) SARS-CoV-2 cell entry depends on ACE2 and TMPRSS2 and is blocked by a clinically proven protease inhibitor. Cell 181:271-280.e8. https://doi.org/10.1016/j.cell.2020. 02.052

36. Wang K, Chen W, Zhou Y-S, Lian J-Q, Zhang Z, Du P et al (2020) SARS-CoV-2 invades host cells via a novel route: CD147-spike protein. Biorxiv. https://doi.org/10.1101/2020.03.14.988345

37. Pastorino B, Touret F, Gilles M, de Lamballerie X, Charrel RN (2020) Prolonged infectivity of SARS-CoV-2 in fomites. Emerg Infect Dis 26(9):2256-2257. https://doi.org/10.3201/eid2609. 201788

38. Riddell S, Goldie S, Hill A, Eagles D, Drew TW (2020) The effect of temperature on persistence of SARS-CoV-2 on common surfaces. Virol J 17(1):145. https://doi.org/10.1186/s12985-02001418-7

39. van Doremalen N, Bushmaker T, Morris DH, Holbrook MG, Gamble A, Williamson BN et al (2020) Aerosol and surface stability of SARS-CoV-2 as compared with SARS-CoV-1. N Engl J Med 382(16):1564-1567. https://doi.org/10.1056/NEJMc2004973

Publisher's note Springer Nature remains neutral with regard to jurisdictional claims in published maps and institutional affiliations. 